\title{
RELATIONS BETWEEN WILLOW PTARMIGAN (LAGOPUS LAGOPUS) DENSITY AND GYRFALCON (FALCO RUSTICOLUS) BREEDING PERFORMANCE IN SWEDEN
}

\author{
Ulla Falkdalen ${ }^{1}$, Maria Hörnell-Willebrand ${ }^{2}$, Torgeir Nygåro ${ }^{3}$, Tomas Bergström ${ }^{4}$, \\ GunNar Lind ${ }^{1}$, AlF Nordin ${ }^{1}$, AND Bengt WarensJö ${ }^{1}$ \\ ${ }^{1}$ Project Gyrfalcon, Frösö-Berge 110, SE-832 96 Frösön, Sweden. \\ E-mail: gyrfalco@gmail.com \\ ${ }^{2}$ Hedmark University College, Faculty of Applied Ecology and Agricultural Sciences, \\ Evenstad NO-2480 Koppang, Norway
}

${ }^{3}$ Norwegian Institute for Nature Research, Trondheim, Tungasletta 2, NO-7485, Norway

${ }^{4}$ Provincial Administrative Board of Jämtland, SE-831 86 Östersund, Sweden

\begin{abstract}
EXTENDED ABSTRACT.-The availability of ptarmigan is considered a key factor for successful breeding of Gyrfalcons (e.g., Cade et al. 1998, Hagen 1952, Koskimies 1999, Potapov and Sale 2005). In many parts of Europe, Lagopus spp. often represent over $90 \%$ of the Gyrfalcon's diet during the breeding season (Koskimies and Sulkava 2002, Nielsen 2003, Nystrom et al. 2005). Willow Ptarmigan (Lagopus lagopus) is the most important prey for the Finnish Gyrfalcon population (Koskimies 2005) while Rock Ptarmigan (Lagopus muta) is the main prey in Iceland (Nielsen 2003), and an important part of the diet in the high alpine areas in Sweden and Norway (Nystrom et al. 2005). This study, focusing on the spatial and temporal relations between ptarmigan density and Gyrfalcon breeding performance, analyzed data from 55 Gyrfalcon territories and ten ptarmigan census areas in Central Sweden at $63^{\circ}-64^{\circ} \mathrm{N}$ between 1996 and 2010.
\end{abstract}

This study was conducted in the mountain region administrated by the Provincial Board of Jämtland, Sweden. It is covered by about $75 \%$ alpine heath and shrub land and $25 \%$ mountainous conifer boreal forest with mixed pine (Pinus sylvestris) and spruce (Picea abies). We counted the number of adult and young Willow Ptarmigan in early August, before the hunting season, to estimate ptarmigan densities by distance sampling (Buckland et al. 2001). The counts were performed using pointing dogs along transect lines. Dog handlers were carefully recruited and received training and evaluation on an annual basis. Transect lines covered areas below $1100 \mathrm{~m}$ above sea level. Lines were placed $400 \mathrm{~m}$ apart, and total transect lengths varied between 78 and $151 \mathrm{~km}$. The number of chicks per adult, including unsuccessful birds, recorded during the counts was used to measure per capita breeding success. The areas counted were part of a nationwide monitoring program (see Hörnell-Willebrand 2005 for further details).

The Gyrfalcon monitoring was done each year in April by 10-15 volunteers and rangers from 
the Provincial Administrative Board of Jämtland using skis or snowmobiles to cover all known nest sites in the mountain range of Jämtland and Härjedalen. Each site was watched for a minimum of two hours to determine the presence or absence of Gyrfalcons. A second monitoring round was done by foot or helicopter in June to establish breeding results.

The monitoring area in the Province of Jämtland (Jämtland and Härjedalen counties) covers ca. $8,000 \mathrm{~km}^{2}$. The number of Gyrfalcon territories was in the range of 31-55 during the period 1996-2010. The minimum estimate is the maximum number of occupied territories in one and the same year. The maximum estimate is the sum of all different occupied territories, based on all years during that period.

Willow Ptarmigan densities and breeding success in the 10 monitoring areas were analyzed together with 16 Gyrfalcon territories within $11 \mathrm{~km}$ of such areas. An analysis of 23 territories closer than $21 \mathrm{~km}$ from census lines gave similar results and are not shown here. We assumed that total density or breeding success for Willow Ptarmigan estimated in autumn was a good indicator of food availability for Gyrfalcons the next spring. We evaluated the relationship between the Gyrfalcon breeding performance and territory occupancy and the total Willow Ptarmigan density, adult density and breeding success in the Willow Ptarmigan monitoring areas in year $t, t-1$ and $t-2$ to account for the effect of food availability, by a generalized linear model (GLM). Overdispersion was detected in the model, so the error structure was corrected using a quasi-GLM. The minimal adequate model of a multiple regression was obtained by following a backward step-wise approach. Variables with a significance value of $\mathrm{P}>0.05$ were excluded. We used R (R Development Core Team 2010) for all statistical analyses.
The average reproductive rate of Gyrfalcons during the period 1996-2010 was 2.74 chicks per successful breeding, while it was 1.33 per occupied territory. In the study area, $14 \%$ of Gyrfalcon territories produced $50 \%$ of the chicks. The number of occupied territories during any one year varied between 16 and 31 , while the number of successful breeding attempts varied between five and 17 . The average territory size was estimated at 150 $\mathrm{km}^{2}$. Reproductive rates of Gyrfalcons from 1996-2010 in the Province of Jämtland followed a three-year cycle and there was a high positive correlation between the number of breeding pairs and the number of Gyrfalcon chicks produced three years earlier $\left(\mathrm{R}^{2}=\right.$ $0.32, \mathrm{P}<0.02$ ) (Figure 1).

Analysis of Gyrfalcon territories in or close to Willow Ptarmigan monitoring areas showed a weak positive relationship between total Willow Ptarmigan density and successful Gyrfalcon breeding $(\mathrm{F}=3.14, \mathrm{P}=0.078)$. The best predictor of Gyrfalcon reproductive success was the production of Willow Ptarmigan chicks in year $\mathrm{t}-1,\left(\mathrm{R}^{2}=0.63, \mathrm{P}<0.02\right)$ (Figure 2), and a weaker correlation was shown with the density of adult Willow Ptarmigan in year $\mathrm{t}-1\left(\mathrm{R}^{2}=0.48, \mathrm{P}<0.07\right)$. No significant correlations were found between Rock Ptarmigan densities and Gyrfalcon breeding parameters.

In a previous study in two northern provinces (Norrbotten and Västerbotten) in Sweden, there was no correlation between the Gyrfalcon population and the Willow Ptarmigan population at the province level with any time-lag. But on the local level, adult Willow Ptarmigan density close to Gyrfalcon territories explained both the proportion of occupied territories and the number of young Gyrfalcons produced the same year (HörnellWillebrand 2008). This means that the Gyrfalcon population in northern Sweden tracked prey densities without a time-lag, contrary to what previous studies in Iceland have shown, where a two- to three-year time-lag has been 
demonstrated (Nielsen 1999). Interestingly, the results from our study in the Province of Jämtland showed a strong correlation between Willow Ptarmigan numbers and Gyrfalcon breeding parameters, with a time-lag of one year. High numbers of juvenile Willow Ptarmigan in autumn seemed to result in a good population of juvenile Willow Ptarmigan over the winter, benefiting the breeding condition of Gyrfalcons the next spring, in accordance with the low natural mortality of Willow Ptarmigan during winter (Sandercock et al. 2011). Data from yearly ptarmigan counts on state land in Northern Sweden indicate cycles of 10-12 years in that region (M. Willebrand, unpublished data), while our data from Jämtland show cycles of 2-4 years. These geographical differences in the length of ptarmigan cycles could be a key factor regarding the Gyrfalcon's response to ptarmigan abundance and the time-lag involved. One other reason could be connected to the recent irregularity in vole cycles and the impact of other predators on ptarmigan numbers. Competition from Golden Eagles (Aquila chrysaetos) and from ground predators such as foxes and mustelids on ptarmigan in low vole years may play a role, as ptarmigan and vole peaks are not always synchronized (Hagen 1952). In Iceland, where voles are absent and Rock Ptarmigan (the only ptarmigan on Iceland) undergo ten-year cycles, a delayed numerical response between ptarmigan densities and the number of breeding Gyrfalcons is shown (Nielsen 1999).

The correlation between the Gyrfalcon productivity in Jämtland and the proportion of occupied territories in year $\mathrm{t}+3$ may reflect the average age at which the young birds normally enter the breeding population, as they are known to start breeding at 2-4 years of age (Booms et al. 2008).

The lack of correlations between Gyrfalcon and Rock Ptarmigan could be biased by the fact that few of the census lines covered extensive Rock Ptarmigan habitat. In alpine

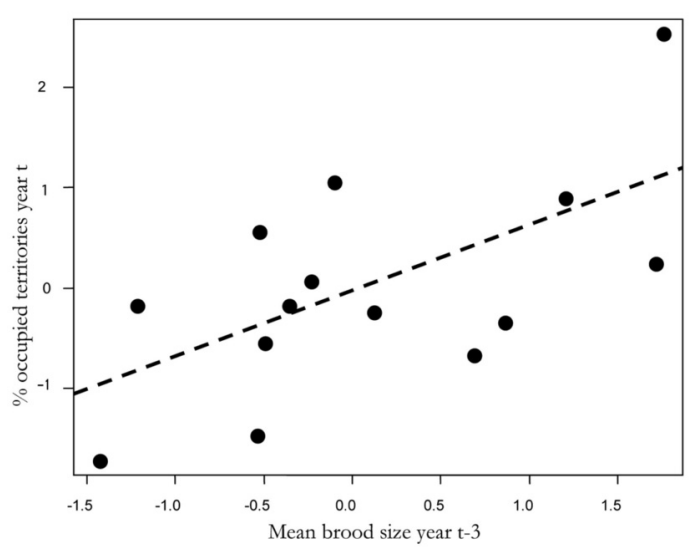

Figure 1. The correlation between mean brood size of Gyrfalcons in Jämtland in year t-3 (on X axis), and the \% of occupied territories in year $t$ on the $Y$ axis (normalized values).

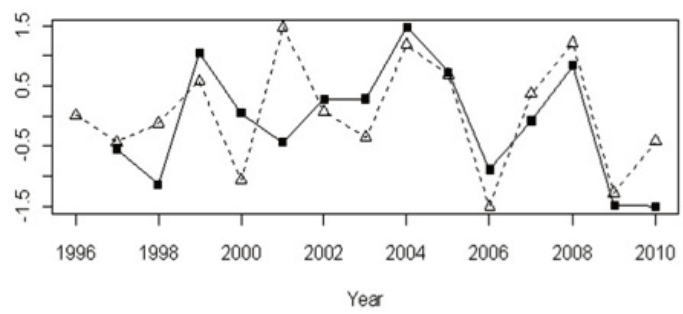

Figure 2. The broken line is the proportion of successful breeding attempts per visited territory of Gyrfalcon in year t. The solid line is reproductive rate of Willow Ptarmigan in year $\mathrm{t}-1$ (number of chicks per pair in second week of August). Normalized values.

territories at high altitudes, one would expect a positive correlation. The ptarmigan census lines were primarily designed to target Willow Ptarmigan, although a significant number of observations of Rock Ptarmigan were made during censuses. We have, however, insufficient information on their densities at high altitudes where a correlation between Gyrfalcons and Rock Ptarmigan could be expected.

Although the vole cycles of Fennoscandia have shown less regularity and with lower peaks in recent decades than historically (Hörnfeldt et 
al. 2005), the fluctuations of Gyrfalcons seems to have kept their regular cyclicity.

The finding that $14 \%$ of the Gyrfalcons produced $50 \%$ of the offspring in this population as a whole during the study period highlights the importance of high quality territories, or high quality females, or a combination of both. Perhaps it applies to males as well, as the species is considered monogamous (Cade et al. 1998). The importance of high quality females was also found in European Sparrowhawks (Accipiter nisus), where $15 \%$ of the breeding females produced $50 \%$ of the chicks (Newton 1986). Received 10 September 2011, accepted 19 September 2011.

Falkdalen, U., M. Hörnell-Willebrand, T. NygÅRd, T. Bergström, G. Lind, A. Nordin, AND B. WARENSJÖ. 2011. Relations between Willow Ptarmigan (Lagopus lagopus) density and Gyrfalcon (Falco rusticolus) breeding performance in Sweden. Extended abstract, pages 171-176 in R. T. Watson, T. J. Cade, M. Fuller, G. Hunt, and E. Potapov (Eds.). Gyrfalcons and Ptarmigan in a Changing World, Volume II. The Peregrine Fund, Boise, Idaho, USA. http://dx.doi.org/10.4080/ gpcw.2011.0217

Key words: Gyrfalcon, ptarmigan, breeding, reproduction, cycles, Sweden. 


\section{Literature Cited}

Booms, T. L., T. J. CADE, AND N. J. Clum. 2008. Gyrfalcon (Falco rusticolus). In A. Poole (Ed.). The Birds of North America Online. Cornell Laboratory of Ornithology, Ithaca, New York, USA. Retrieved from The Birds of North America Online database: http://bna.birds.cornell.edu/bna.html/ species/114

BuCKLAND, S., D. R. ANDERSON, K. P. BuRnHAM, J. L. LAAKE, D. L. BORCHERS, AND L. Thomas. 2001. Introduction to Distance Sampling: Estimating Abundance of Biological Populations. Oxford University Press, Oxford, UK.

Cade, T. J., P. Koskimies, And Ó. K. Nielsen. 1998. Falco rusticolus Gyrfalcon. BWP Update 2:1-25.

Hagen, Y. 1952. Rovfuglene og Viltpleien [Birds of Prey and Game Management]. Universitetsforlaget, Oslo, Norway.

HÖRNELL-WILlEBRAND, M. 2005. Temporal and spatial dynamics of Willow Grouse Lagopus lagopus. Ph.D. thesis, Swedish University of Agricultural Sciences, Umeå, Sweden.

HÖRNELL-WiLlebrand, M. 2008. Korrelation mellan dalripa (Lagopus lagopus) och Jaktfalk (Falco rusticolus) [Correlation between Willow Ptarmigan and Gyrfalcon]. Project report. Naturvårdsverket, Stockholm, Sweden.

HÖRNFELDT, B., T. HIPKISS, AND U. EKLUND. 2005. Fading out of vole and predator cycles? Proceedings of the Royal Society B 272:2045-2049.

Koskimies, P. 1999. International Species Action Plan. Gyrfalcon Falco rusticolus. BirdLife International \& European Commission, Brussels, Belgium.

Koskimies, P. 2005. Research on conservation biology of the Gyrfalcon Falco rusticolus in Northern Fennoscandia: Present status and future prospects. Pages 56-69 in P.
Koskimies and N. V. Lapshin (Eds.). Proceedings of the Workshop: Status of Raptor Populations in Eastern Fennoscandia. Kostomuksha, Karelia, Russia, November 8-10, 2005.

Koskimies, P., AND S. SulKaVA. 2002. Tunturihaukka elää riekolla ja kiirunalla [Diet of the Gyrfalcon Falco rusticolus in Finland]. Linnut 37:6-10 (summary in English).

Newton, I. 1986. The Sparrowhawk. T. \& A. D. Poyser, Carleton, UK.

NiELSEN, Ó. K. 1999. Gyrfalcon predation on ptarmigan: Numerical and functional responses. Journal of Animal Ecology 68:1034-1050.

NiELSEN, Ó. K. 2003. The impact of food availability on Gyrfalcon (Falco rusticolus) diet and timing of breeding. In D. B. A. Thompson, S. M. Redpath, A. H. Fielding, M. Marquiss, and C. A. Galbraith (Eds.). Birds of Prey in a Changing Environment. Scottish Natural Heritage, The Stationary Office, Edinburgh, UK.

NySTRÖM, J., J. EKENSTEDT, J. ENGSTRÖM, AND A. AngerbJöRn. 2005. Gyr Falcons, ptarmigan and microtine rodents in northern Sweden. Ibis 147:587-597.

Potapov, E., And R. Sale. 2005. The Gyrfalcon. T. \& A. D. Poyser, London, UK, and Yale University Press, New Haven, Connecticut, USA.

R Development Core Team. 2010. R: A Language and Environment for Statistical Computing. R Foundation for Statistical Computing, Vienna, Austria.

SANDERCOCK, B. K., E. B. Nilsen, H. Brøseth, And H. C. Pedersen. 2011. Is hunting mortality additive or compensatory to natural mortality? Effects of experimental harvest on the survival and cause-specific mortality of Willow Ptarmigan. Journal of Animal Ecology 80(1):244-258. http://dx.doi.org/10.1111/j.1365-2656. 2010.01769.x 
- Falkdalen et Al. - 